\title{
Reading Tahitian Francophone Literature: The Challenge of Scent and Perfume
}

\author{
Andrew Cowell and Maureen Denino, University of Colorado
}

\author{
Andrew Cowell and Maureen Denino \\ Department of French and Italian \\ UCB 238 \\ University of Colorado \\ Boulder, CO 80309-0238, USA \\ cowellj@colorado.edu
}

Andrew Cowell is the Chair of the Department of French and Italian at the University of Colorado. He has published most extensively on medieval France. He also works on the Pacific, having published on topics such as Diderot's depiction of Tahiti (in Studies on Voltaire and the Eighteenth Century, 1995), images of cannibalism and nuclear holocaust in the Pacific in film and in National Geographic (in Cultural Studies, 1999), language revitalization in Hawaii (in International Journal of the Sociology of Language, 2012), and the relationship of literature and traditional performance in Tahiti (in Text and Performance Quarterly, 2013). He is fluent in Hawaiian and also speaks Tahitian.

Contact: Department of French and Italian, UCB 238, University of Colorado, Boulder, CO, 
80309-0238, USA

E-mail: cowellj@ colorado.edu

Maureen Denino is a graduate student at the University of Colorado, currently working to complete her Masters degree in French. She is particularly interested in Francophone literatures, and has studied the literature of French Polynesia with Dr. Andrew Cowell and Dr. Lydie Moudileno. Her seminar paper in 2012 was a key initial inspiration for this article. She will pursue her Ph.D. at Princeton.

Contact: Department of French and Italian, UCB 238, University of Colorado, Boulder, CO, 80309-0238, USA

E-mail: Maureen.denino@colorado.edu

Abstract: This article focuses on one particular recent French Polynesian novel, Hutu Päinu:

Tahiti, Racines et Déchirements (2004), and more generally on the issue of how to approach and read Tahitian literature from the 'outside' given the heavily over-determined images of Tahiti in the western imaginary and the still relatively small (but growing) amount of indigenous literary production. The focus is on the poetics and hermeneutics of scent as explored by the author, Marie-Claude Teissier-Landgraf. The article argues that French Polynesian writers generally have been extraordinarily sensitive to over-determination, and that the theme of scent is used to challenge western images of Tahiti as a floral paradise, but also tendencies to idealize scent as a potential postcolonial form of sensory resistance to more containable modes of knowledge, such 
as vision or hearing. The novel suggests that Tahiti remains a powerful object of outside desire, and this desire constantly threatens to foreclose the full potential readings of the local literature.

Résumé : Cet article traite un roman francophone récent de la Polynésie Française, Hutu Pāinu: Tahiti, Racines et Déchirements (2004), et plus généralement, la question de la manière dont il faut s'approcher de la littérature Tahitienne et la lire 'de l'extérieur', en vue du fait que l'image du Tahiti est nettement sur-déterminée dans l'imaginaire occidental, et la voix littéraire locale en français est née seulement depuis trente ans. Le point de départ de l'article est la poétique et l'herméneutique de l'odorat, telle qu'elles sont examinées par l'auteur, Marie-Claude TeissierLandgraf. L'article démontre que les écrivains de la Polynésie Française ont été très sensibles à la sur-détérmination interprétative, et que le thème de l'odorat est employé pour mettre en question à la fois les images de Tahiti comme paradis floral et les tendances à poser l'odorat comme une forme de résistance postcoloniale sensorielle aux connaissances plus faciles à contraindre, comme la vision et l'ouie. Le roman suggère que la Tahiti est toujours un objet de puissants désirs externes, et ces désirs menacent d'appauvrir la richesse potentielle de cette littérature.

Keywords : French Polynesia, Tahiti, islands, scent, perfume, colonial desire 
Ma petite, apprends qu'on ne voit pas Tahiti, on la sent. Elle offre d'abord tous ses parfums aux voyageurs courageux [...] Tu n'as pas besoin de tes yeux pour connaître certaines choses, car ils peuvent te tromper. (Teissier-Landgraf 2004: 19)

In Marie-Claude Teissier-Landgraf's 2004 Tahitian coming-of-age novel Hutu Päinu, these are the words of a Tahitian passenger on a ship arriving in Tahiti from France just after World War II. They are spoken to six-year-old Sophie Rigolet, a half-Tahitian/half-French girl coming to join her father and see for the first time the place where she will grow up after escaping from war-torn France with her French mother. The words of the Tahitian passenger raise a number of interesting points of departure for reading the novel. First of course, the 'parfums' evoke the Western imaginary of Tahiti and Polynesia as a supposed tropical, floral paradise, as described by Cook and Bougainville, and reinforced by later writers. ${ }^{1}$ Then as the clouds part and the passengers gaze at the island from aboard the ship, one could recall familiar images of the island utopia more generally, so desired by seafaring explorers (Edmond and Smith 2003: 2-3).

The scene immediately complicates these perspectives however, since the arriving Tahitians themselves - and Sophie in particular - are the 'voyageurs'. This complication is the central focus of the novel, explored in particular through the experiences of Sophie, a démie in local parlance. To what extent are all Tahitians 'voyageurs,' figuratively or literally displaced from their own islands, the scene seems to ask. Given this potential displacement, one can also wonder to what extent the words of the Tahitian reflect the adoption of the vision of the French colonizers themselves. On the other hand, the words also hint at a more local understanding of 
the idea of perfume and the sense of smell. In particular, the passenger's words suggest the possibility of a different hierarchy and ontology of bodily senses in Tahiti in comparison to Western European experience, privileging the sense of smell in particular, and the lower bodily senses in general over, the higher ones of vision and hearing. This privileging of the lower senses is highly problematic in a Western European social and intellectual context, where odors are often perceived as invasive and undesirable, or as dangerously -- yet invitingly -- sexual.

The scene can certainly also be read as positing the vast majority (perhaps all?) of the readers of the text as outsiders and voyagers as well, whether to Tahiti or figuratively to its local literature. How then, might we approach and read Tahiti in general and the novel in particular in light of the evocations of this Tahitian voyager? In this article, we begin with a contextualizing overview of possible readings of the passenger's words, ranging from Western European and colonial attitudes towards smell and odors to postcolonial artistic efforts to construct an olfactory poetics. Then through a close examination of the novel's rich and diverse depiction of the 'parfums' of Tahiti, we will explore a particular -- and particularly Tahitian -- 'poetics of scent' that both reflects and resists the motifs evoked by this opening scene. Theoretically, as the contextualizing overview suggests, we want to insist that this novel and its poetics of scent can be read most productively in light of critiques of the notions of 'culture' and 'place' as unitary and homologous forms (see Clifford 1988, Gupta and Ferguson 1992) marked by disjunctions from other cultures and places. The term 'Tahiti' should be taken to represent a place, not a culture, and a place traversed by a complex blend of cultures. Nevertheless the novel does posit a sense of local place (and smell) that resists the notion of global French culture and 'littérature monde' (see Hargreaves, Forsdick and Murphy 2010). 


\section{The Sense of Smell and Olfactory Poetics: Transnational Perspectives}

From the broadest historical and geographical perspective, the hierarchy of the senses, with vision at the top and smell often at the very bottom, has a long history in European thought, beginning with Plato and Aristotle, and notably emphasized by Kant in his aesthetics (see Corbin 1986: 7, Classen, Howes, and Synnott 1994: 84-85, Shiner and Kriskovets 2007: 275, and Curtis 2008: 10). The downgrading of the sense of smell in the domains of philosophy and aesthetics has typically rested on several criteria: that it is related to the ephemeral rather than the permanent, since most smells are difficult or impossible to preserve or exactly reproduce (see Corbin 1986: 7, and Classen, Howes and Synnott (1994: 3); that it is non-cognitive or nonintellectual, lacking an adequate vocabulary and thus the possibility of discursive analysis, control and stability; that it is more closely connected to mere bodily experience than mental reflection (see Classen, Howes and Synnott 1994: 3, Batty 2010: 1137 - though she goes on to challenge this claim, and Curtis 2008); and that smells are part of the secondary, subjective experience of an encounter with an object, rather than an objective form of knowledge of the object itself. Thus noted art critic Roger Scruton argues that while the visual sense (particularly in the aesthetic domain) involves a direct engagement with the object of vision, the sense of smell involves only a secondary internal experience derived from the object (Scruton 1979: 114).

In the European experience, this intellectual dismissal of the sense of smell has been accompanied - especially in the nineteenth and twentieth centuries - by the sociological degradation of smell (see Corbin 1986: 4-5, 143-48, Classen, Howes and Synnott 1994: 161-68, Terranova 2007: 137-53, and Curtis 2008). In The Foul and the Fragrant, Alain Corbin shows how the sense of smell in the European imaginary of the nineteenth century came to be 
associated with the refreshing scents of the flower garden and perfumes, but also with lower bodily functions such as lust, defecation, and putrefaction. These latter associations in particular linked smell to the savage and the animal:

Sniffing and smelling, a predilection for powerful animal odors, the erotic effect of sexual odors - all become objects of suspicion. Such interests, thought to be essentially savage, attest to a proximity to animals, a lack of refinement, and ignorance of good manners. In short, they reveal a basic failure at the level of social education. The sense of smell is at the bottom of the hierarchy of senses, along with the sense of touch. (Corbin 1986: 7)

These attitudes accompanied a movement of social sanitation, which sought to suppress smells and protect the individual from strong odors, and secondarily, to carefully compartmentalize smells in relation to social times and spaces (see Corbin 1986: 161-74, and Curtis 2008). As a result, vision in particular (and also hearing) were linked to power and intellect, while smells, the sense of smell and the act of sniffing were linked to the marginalized, the disempowered, and the animalistic. The French bourgeoisie of the later nineteenth century not only sought to suppress their own bodily odors, but constructed large individual homes which both protected them from the smells of the street and the lower classes, and also allowed for different rooms (kitchen, parlor, boudoir) where different smells could be contained and compartmentalized. Thus in addition to the philosophical and aesthetic objections to smell can be added sociological ones: it is supposedly emblematic of the lower classes, and it tends to be pervasive and difficult to control, assaulting one despite efforts at self-protection, in ways that many other sensual 
experiences do not (see Curtis 2008: 10, Jackson 2011, Classen, Howes and Synnott 1994: 17375, and Corbin 1986: 43). In this context, smells were and are used to diagnose social ills and undesirables, and to exercize broader social control via the control of smells. Un-controlled smells could be seen as a threat to the social order as well as the aesthetic order (see Terranova 2007, and Classen, Howes and Synnott 1994: 4-5).

As is so often the case, paradigms of power and hierarchy in operation within European society were transferred to - or from - colonial settings; smell became associated with the savage and the Other. Anthropologist Deborah Jackson theorizes the sense of smell in terms of its powerful 'embodiment of the perceived substance,' which thereby connects the individual experiencer of the smell to that odor's locality and origin in especially powerful ways (2011: 606). Writing about air pollution, she notes how it 'invades' peoples' lives and bodies in 'especially insidious ways' (2011: 610). Drawing on the work of Drew Leder, she argues that the body 'seizes' such sensory inputs and can become 'other and opposed to [it]self' (2011: 614) as a result. Drawing on the more psychological approaches of Casey Edwards, she concludes that the 'groundedness' of the experience of smell in the body can lead to a sense of 'dread' (2011: 614). Thus efforts to control the sensorium in relation to either the colonized subject abroad or the immigrant at home were commonplace, and continue to this day. In present-day Canada, Pakistani immigrants are confronted with a 'sanitized sensorium' which demands the suppression of 'foreign' food odors on the person, and carefully restricts the acceptability of these odors more generally to ethnic food festivals and similar restrictive events; smell becomes intimately connecting to the othering of immigrants (Ameeriar 2012: 510, 515-6). To put it bluntly, in the minds of European colonizers, colonized peoples and recent migrants 'stink' (see also Lai 2008, 
and Terranova 2007). It is worth noting that the notion of stench has a double valence: it classifies unpleasant smells, but also in some cases excessively strong smells generally.

Though the devaluation of the sense of smell has a long international and historical pedigree, the employment of a 'poetics of scent' which responds to and resists this devaluation is also widespread. A number of artists internationally have sought to develop such a poetics, which works in opposition to the traditional philosophical, aesthetic and sociological objections to scent. One aesthetic-philosophical example would be the Brazilian artist Ernesto Neto, whose installation of hose filled with various spices sought to pervade the spectator with an embodied sensory experience aimed at 'mending the fracture between mind and body' (Shiner and Kristovets 2007: 273). A much more sociological example is Angela Ellsworth's decision to wear a stylish dress soaked in her own urine to her art opening, thus examining how smell 'permeates the space and transcends visual barriers' and 'destroys any social boundaries' (Shiner and Kristovets 2007: 273). Much more overtly postcolonial is novelist Larissa Lai's text Salt Fish Girl, which focuses on the stinky body of its protagonist. In the words of one critic:

The novel's insistence on strong, foul smells as an aspect of past and future worlds rescripts what Walter Ong calls our 'sensorium'-the sensory apparatus as an operational complex — by privileging the olfactory sense rather than relegating it to primitive temporalities; foul odors jolt us into rethinking our assumptions about modernity and knowledge. Precisely because these smells disgust us, they perform what historian William Ian Miller explores as disgust's centrality to civilization's 'social control and psychic order’. (Paul Lai 2008: 168) 
Certainly these examples could be multiplied, but they all rely broadly on a thematic and poetic focus on smell's ability to erase boundaries, invade bodies and individual subjective experience, evade established discourse, and resist efforts at objectification and control. Note also the reliance on strong and/or objectionable smells in many cases, as well as a tendency to juxtapose smells (urine among the perfumed women of an art opening, for example) in striking ways. From the perspective of the more specifically French tradition within which Teissier-Landgraf partially writes, one could trace this poetics of scent back to Baudelaire, Zola, and especially the decadence of Huysmans (where the focus on the disgusting and objectionable is most developed), and in another valence to the work of Colette, though she focuses more on the importance of scent and juxtapositions of scent generally, and much less on the element of disgust (see Corbin 1986: 200-21, Classen, Howes and Synnott 1994: 86-7, Kern 1974: 820-2, and Feigenbaum 2004 on Colette). In its more recent incarnations, the appeal of such a poetics to liberal social critics generally is obvious, and its attractiveness for postcolonial resistance to discursive and social control and domination is equally clear.

\section{Smell and the Lower Bodily Senses: Local Resonances in Hutu Päinu}

One might object that Tahiti, in the European imaginary, has a very different valence from virtually all other colonial locations with regards to smell, combining both attractive smells (also connected with locations such Sri Lanka and Indonesia/“The Spice Islands" of course) with easily available sexuality. Even more importantly, the passenger speaking the lines with which we began is herself Tahitian, not European, and the broader Polynesian sensorium places an extremely high value on the sense of smell, to the point that it could be argued to be the highest 
of the senses in Tahitian - and even more so Hawaiian - indigenous artistic traditions. The writings of Epeli Hau'ofa, while not notably focused on olfactory issues, provide yet another context for reading the opening lines within a specifically Pacific context. He argues for the interconnectedness of the Pacific island states, positing a 'sea of islands' rather than 'islands in a far sea' (Hau'ofa 1994 :7). The opening scene of the novel, where the passengers eagerly await their arrival in Tahiti from the decks of the ship, recalls the European imaginary of islands as bounded entities, ideal controllable spaces entirely visible from aboard a ship (see Edmond and Smith 2003, especially the Introduction and chapters 4, 5, 6 and 8). But it also situates the Tahitian passengers as representatives of Hau'ofa's 'ocean peoples': their ability to sense the island before it is visible erases the supposed boundaries of sea and land and allows the island's presence to extend far beyond its visual confines (Edmond and Smith 2003:9-11) - much as scents more generally pervade spaces far beyond the range of their sources.

The opening encounter scene of Teissier-Landgraf's novel - and many other scenes as well, as we will see - can thus be situated within many broader contexts beyond that of "fragrant Tahiti”: Western intellectual history, aesthetics, and social change; colonial models of order and discipline; the European imaginary of islands; specifically French social history of the Second Empire and Third Republic; an international poetics of smell; the postcolonial deployment of that poetics; Polynesian and Oceanic models of islands and the role of smell; and specifically French artistic developments of the turn of the nineteenth century. Our purpose here is not to explore potential connections to the all these sources in detail. Rather, we want to consider how this text resonates against all of these sources while also providing a particularly local, Tahitian inflection to the question of scent. 
Sophie's arrival in Tahiti triggers a wave of sensations that echoes the words of the experienced passenger on the boat, as she discovers the island through the myriad sights, sounds, and especially smells it offers. It is not merely the image of Tahiti as fragrant floral paradise that prevails, however. Sophie seems to show an equal predilection for - to borrow Alain Corbin's formulation - both the foul and the fragrant. On her arrival in the capital, Pape'ete, it is first the strange odors wafting from the nearby Chinese stores that intrigue and fascinate her: 'Ce sont les magasins chinois de la capitale, aux intérieurs sombres d'où sortent d'étranges effluves. Comme tout cela est mystérieux et fascinant ! Elle aimerait s'échapper tout de suite et s'immerger, seule, dans ce monde inconnu' $(23) .^{2}$ In contrast, two pages on, she marvels at the more traditional Oceanic image of a house on the lagoon, scented by the salt of the sea, in a scene more fitting of exoticizing postcards of as island paradise than the sometimes miasmal odors wafting from the Chinese stores: 'Le parfum iodé du lointain récif chauffé par le soleil, le clapotis des vaguelettes, la course poursuite d'une multitude de poissons bariolés, ravissent la fillette. La nature est partout, prête à se laisser découvrir et apprécier. "Il faut si peu pour être heureux ici”, se dit-elle' (25). This close juxtaposition of the foul and the fragrant is characteristic of Sophie's experience throughout the text. In these two scenes, seemingly opposite in their presentation of Tahiti, we find a common thread in Sophie's reaction: in both cases, a desire to explore, regardless of the nature - foul or fragrant - of the experience. The island, encompassing both strange-smelling Chinese stores and idyllic lagoons, offers itself up to her eager senses, as she discovers a range of sensations that both enthrall and confuse, but never repulse, her. A close look at the many scenes of discovery reveals that even in those instances where the reader might well be disgusted, 
Sophie herself expresses only wonder and curiosity; nor does the narration include any negative judgments on these kinds of experiences.

Later for example, Sophie and her family get a surprise in their new home's bathroom worms that wriggle to the surface to squirm in the soapy water under their feet - the experience is presented not as disgusting, but simply as 'inoubliable':

Le sol cimenté, cassé en plusieurs morceaux sous la douche, réserve aussi une surprise. Une colonie de vers de terre roses remontent en se dandinant à la surface de l'eau savonneuse dès qu'elle stagne un peu trop longtemps. Une planche posée sur les parties disjointes deviendra vite glissante, transformant la toilette en exercice funambulesque. Tomber dans une des flaques mousseuses et sentir les vers grouiller sous la plante des pieds seront pour Sophie une autre expérience inoubliable. $(47)^{3}$

Words like 'glissante', 'flaques mousseuses' and 'grouiller' emphasize the role played by the sense of touch in this highly evocative scene. There is an openness towards all sensations, which does not discriminate between high (sight, sound) and low (touch, taste, smell). Sophie seems to want to accumulate experiences of any kind, but in particular experiences that contrast with her mother's French expectations of sanitation and compartmentalization, as in the following scene, where, during a promenade along the beach, Sophie comes across a man seated in a wooden structure. Approaching to greet him, she quickly realizes he is in a kind of open outhouse, thanks to 'une certaine odeur': 
Rouge de honte, elle lui tourne le dos, et s'éloigne vivement. Elle remarque alors la présence d'autres fare iti [...] La curiosité aidant, elle remarque que certains possèdent la réserve classique de feuilles de papier immobilisées sous un morceau de corail ; d'autres sont approvisionnées en feuilles de $p \bar{a} r e u[. .$.$] Ses premières réactions d'embarras$ passées, elle se dit qu'après tout, ce sont les plus beaux cabinets du monde, avec vue plongeante sur la mer et sur Moorea. Et puis, pourquoi avoir honte et se cacher derrière une porte fermée ? Ces habitants savent vraiment embellir leur vie à chaque instant! (156)

Here we have an odor, defecation, that habitually serves as a warning, but which is not met with the usual response; after an initial feeling of shame and a desire to flee, Sophie's curiosity takes over and leads not to a disgusted rejection but to an appreciation of Tahitian savoir vivre that does not enact the a Western separation of foul odor and beautiful view. Sophie explicitly contrasts European prudery with Tahitian openness, wherein the very characterization of certain smells as foul is rejected. This openness and resistance to negative sense associations recalls Larissa Lai's Salt Fish Girl, where the main character is imbued with a 'stink' recalling durian, the pungent tropical fruit. As with Sophie and the myriad odors of Tahiti, Lai's protagonist, Miranda, 'through much of her childhood [...] does not associate her smell with anything shameful or foul' (Paul Lai 2008: 180). The negative judgment is imposed externally: 'The reactions of others, though, impose a judgment as to which smells are foul and which fragrant' (Paul Lai 2008: 180). The comparison is instructive in that it underlines the particularly 'disruptive quality of smells' and the sense of smell as 'an especially intimate form of knowledge, blurring the boundaries between the smeller and the smelled' (Paul Lai 2008: 183). 
Sophie's obvious desire to explore these kinds of boundary-blurring experiences points to a possible reversal -- or even refusal -- of the European hierarchy of the senses.

Along with smell, the sense of hearing is often viewed as invasive: the body, unprotected, can easily be assailed by loud and unpleasant noises. The description of the Pape'ete neighborhood where the Rigolet family comes to live reveals an onslaught of smells and sounds, from a panoply of cultural sources. The vocabulary emphasizes the violent and invasive nature of the sounds and smells, while also drawing attention to their contrasts and variety. To one side of the new house is a mother-of-pearl polishing factory, where a burning odor produced by the polishing process is doubled by the deafening sounds that bombard the house: 'une vibration profonde, un bruit de tonnerre [...] le travail produit des sons stridents qui transpercent les tympans' (48). In addition, the mostly lower-class Chinese workers begin their day with 'un spectacle sonore tout aussi éprouvant' (48), as they clear their nostrils and throats of the pollution from the factory, noisily sending gobs of mucus flying great distances and adding an element of would-be disgust to the battery of sounds. On the other side of the Rigolet's house lives a Tahitian family, whose matriarch spends the afternoons listening to the same four Luis Mariano songs from a record given to her by a former Popa'a (white European) lover. From the house of another, more refined Chinese family across the street Sophie hears the 'cliquètement des heurts de jetons accompagnés de vives exclamations' and 'une voix nasillarde féminine chant[ant] en chinois sur des mélopées étranges [...] en compétition avec celle de Luis Mariano' (49-50). The bar down the street assails the house with noises 'de bouteilles et de verres entrechoqués, des notes de guitare, des chansons, puis des invectives de bagarre' (50), in addition to the drunks who cross the street to urinate on the edge of their property. Finally, the family's sleep is troubled by the movie theatre behind the house: 
[...] la maison baigne phonétiquement dans l'action des films. Les westerns avec attaques armées sont les pires : pas une minute de répit. Au cours des semaines, elle apprend à somnoler durant les passages tristes ou romantiques bercés de musique douce. Puis elle ne se réveille plus qu'aux cris des acteurs qu'on égorge et qu'aux sifflements de trains.

Remarkably, Sophie's reaction to this battery of multi-cultrual sensations is again pure wonder, as she exclaims: 'Quel quartier! Et les surprises se poursuivent' and 'en effet, la découverte du quartier est passionnante' (50). The pattern of this passage, in which Sophie responds to a diversity of smells and sounds, as well as sights, with the same eager curiosity and amazement, is repeated throughout the novel.

One of the most arresting and stylistically dazzling sections of Hutu Pāinu, 'Les Fêtes du Tiurai' ('The Festival of July') recounts the Tahitian celebrations surrounding the French national holiday of July 14. It is also the chapter in which sensations of smell and touch are richest and most varied, though certainly vision and sound are not neglected. The central role of fragrance in denoting festive spaces has been explored theoretically by Lucienne Roubin. The examples Roubin uses, however, all denote 'fragrant' smells as positive. Conversely, 'dirty water smelling of slime' is used in one festival to mark a monstrous being come to attack the participants (2006: 128-135). Roubin emphasizes the dangerous nature of 'the malodorous' as opposed to 'the pleasant influx' (135). In contrast, Sophie's experience at this festival both blurs and expands the 
boundaries of permissible smells in a festival space. As the chapter opens, 'la rue résonne d'un bruit lointain s'amplifiant peu à peu en un vacarme rythmé, qui envahit tout l'espace ambiant et fait vibrer intérieurement le corps tout entier' (105). Ironically, the author's rich vocabulary of sound here serves to describe not a communicative event, but a corporeal experience closer to dance. Not long after this, 'la bonne odeur de beignets firifiri chauds envahit les rues' (105). The theme of sensory invasion is repeated, underlining the difference between these types of experiences and the carefully controlled visual and auditory circumstances of Sophie's home where her mother attempts to discipline and control - and especially school, where the Catholic sisters explicitly forbid all things Tahitian.

Later, 'soudain le son des tambours explose' (108), and 'le jeu du tā'iri hō' $\bar{e}$ l'émerveille...créant en son milieu des sons graves et résonnants, et aux extrémités des sons aigus et secs. Une indicible envie de danser l'assaille' (108). Again the theme of 'resonance' and its connection to the body and dance is evoked, while the term 'invasion' is augmented by the closely allied 'assault,' again underlining the way in which it is difficult to shield and control bodies exposed to these sensual experiences. The situation reaches an orgiastic climax as 'les sons gambadent, s'appellent, se répondent, s’unifient un instant, puis disparaissent, cédant la place aux chants entonnés par une foule rieuse et débonnaire...toutes races confondues’ (109). Soon the entire crowd breaks out into dance, 'les corps s'agitent aussitôt, frénétiquement' (111). Both the power and the confusing ephemerality of this non-linguistic sound are made clear: categories of age, gender, race and class briefly vanish into the form of the 'crowd'. This type of sound not only invades individual bodies in potentially threatening ways which can overcome linguistic and discursive modes of control exercized through speech and text, but melds bodies together in an undifferentiated, uncontrolled mass. Indeed, 'les danses folkloriques ont très 
mauvaise presse à l'école', Sophie knows, (110; italics our own), and her mother adds that 'ces indigènes n'ont vraiment aucun goût' (112).

Immediately following this scene, the text ironizes on the word 'taste'. First local beer, fresh orange juice and sugar cane are 'dégustés' in the open air, 'parfumée de l'odeur des récifs' (112). These lines mock the French metaphorical 'tastes' mentioned by Sophie's mother by confronting them with the concrete tastes of Tahiti, and also return us to the theme of strong smell, the sensation so opposed to French bourgeois 'good tastes'.

Frustrated by the mother's judgments, Sophie's father leads the family to a place of 'agréables odeurs' and 'l'arôme de l'épice fraîche' (113), but instead of more evocations of the tropical breezes and oceans of Tahiti, we find ourselves - in an echo of Sophie's earlier fascination with the Chinese shops of Pape'ete - in a Chinese restaurant, where it turns out that the family is being fed dog without the mother's knowledge. As they leave the father reveals what was on the menu and Sophie 'regarde sa mère et voit sa gorge agitée de soubresauts puis secouée par des vomissements' (113), as the text veers from the delicious to the disgusting. Yet the agitated rhythmic movements of her mother's throat in some sense echo the movements of the dance: it too is frenetically 'agitated'.

Immediately afterwards, the family encounters a tubercular Chinese ice-cream vendor with a mobile cart. 'Il a la fâcheuse habitude de se moucher avec ses doigts et ce cracher de gros mollards jaunâtres de chaque côté de son vélo’ (114), yet Sophie buys some ice cream anyway. Just as the pleasing odors of the restaurants masked tastes disgusting to a French bourgeois sensibility, the pleasures of ice cream on a warm night are associated with the slimy and 
disgusting images of mucus and illness. Almost immediately afterwards, they get the chance to listen to a radio which, in a grotesque echo of the tubercular ice cream vendor 'grésille' and 'crachote', yet at the same time the sounds 'viennent et se retirent comme des vagues' (115), recalling the delicious smells of the ocean, sea breezes and reefs evoked earlier.

The overall result of this vertiginous series of sensual encounters, which ironically echo each other even as the sensations veer from orgiastic delight to retching disgust, is to produce an epistemology of the senses characterized by extreme instability, mobility and ephemerality. At the same time, there is a constant confusion and merging of multiple senses and experiences, a breakdown of simple and neat categories of evaluation and containment. This is echoed by the way that the sounds, smells, tastes and even sights of the festival are presented as powerfully invasive of the body: efforts to isolate and protect the body are constantly undermined and defeated. While this porosity of borders - whether social, sentient/psychological or physical seems unproblematic for Sophie, it is a kind of purgatory for her mother, and for the French religious and social powers-that-be.

In fact, her every step towards the sensual is met with a parallel resistance, as French authority, through the figures of her mother and the Catholic nuns at her Catholic school, puts up obstacles to her discoveries and sensations. Her repeated transgressions of these barriers are nearly always punished by one or the other authority. The very 'effluves' of the capital that intrigue Sophie disgust her mother, and are to be avoided by the type of proper French girl she would like Sophie to be. Constance Classen, David Howes and Anthony Synnott, in Aroma: The Cultural History of Smell, demonstrate how smell occupies a marginalized position in a modern bourgeois society in which the powerful (males) are odorless: women are then 'fragrant' or 
'foul', while 'ethnic groups exude "foreign", "undesirable” odours' and the 'working classes [...] “reek" of poverty and coarseness' (1994: 161). They identify the two-tiered challenge for those on the periphery: either 'attempt to gain respectability by dispelling or masking their presumed ill odour' or 'seek to assert their own olfactory norms, evaluating their olfactory identity as positive and denouncing the false olfactory identity foisted on them by those in power' (Classen et al. 1994: 161). Sophie's mother seeks to class her démie daughter with the solidly respectable and odorless French, while Sophie herself seems to attempt something like what is described as the second option for those on the periphery: an assertion of a positive, Tahitian, olfactory identity.

Most generally, the struggle between discursive modes of control exercized through vision and hearing, writing and speech, against the sensual invasions of the Tahitian festival, recall the 'civilizing' and 'sanitizing' process of nineteenth-century France and Western Europe. The Tahitian festival echoes scenes of the menacing crowd ("la foule") found in French literature of the later nineteenth century - the epitome of the uncontrolled, undifferentiated mass that threatened individual and social order (Barrows 1981). From Sophie's half-Tahitian perspective however, this crowd might better be described as a rich panoply of experiences, symbolic of an epistemology of the body which allows for and even embraces personal invasion, collective experience, and ephemeralities, all mediated by the lower senses, though not excluding the higher ones either. As such, the festival experience is transformed into a powerful resistance to French colonial modes of discursive order and control. Thus it is no accident that, 'l'esprit libéré, elle [Sophie] éprouve du plaisir à bouger son corps et à se deplacer en rythme' (115) in yet another ironic echo, this time of the French celebration of independence and liberty from royal 
tyranny, which is the ostensible occasion for all the events of the chapter. Tahiti seems to escape bourgeois modes of know-ability, through a series of ironic sensual echoes and combinations, marked by their powerful invasiveness, their stimulation of corporeal rhythms, and their ephemerality. ${ }^{4}$

It is important to note here however that Teissier-Landgraf's text shows one clear departure from both the French literary poetics of smell discussed earlier, as well as elements of contemporary Euro-American and postcolonial uses of the theme, as in Angela Ellsworth's urinesoaked dress; whereas those poetics typically rely on overt appeals to a sense of the objectionable and disgusting qua disgusting for much of their effect, Hutu Päinu continually refuses to accept a notion of the 'disgusting', either in the voice of the narrator or that of Sophie - such a judgment only occurs overtly in the voices of the mother and the nuns, or covertly in that of the reader. This is not to say that Sophie or the Tahitians cannot distinguish among scents or do not prefer certain ones over others. Rather, it suggests that in refusing to acknowledge a sensory category of disgust, the text also refuses to acknowledge the social categories of judgment, containment and constraint that have traditionally gone with this sensory category. Rather than the foul versus the fragrant, the text sets up an opposition of openness to smell versus containment. Given this fact, we must also reconsider the status of the opposite sensory category, the fragrant or perfumed, since refusal of socio-sensory judgments would potentially go in both the positive and negative directions. This consideration brings us squarely to the second half of this article - the question of the unique Tahitian specificity of the novel - because the question of appealing fragrance and perfume evokes both the utopian view of Tahiti in the western imaginary, and with it, the question not just of the body, but the female body in particular and the question of sexuality. 


\section{Colonial Sexuality in Tahiti: 'Parfum', Pleasure and Disgust}

In part, even this evocation of fragrant sensuality can be understood more broadly: one commonplace of studies of the senses in the nineteenth century (particularly in France) is that the sense of smell became increasingly linked with sexuality, particularly since at least in polite mixed company, the expression of sexuality through the other senses was increasingly restricted (see Corbin 1986: 177-88, and Classen, Howes and Synnott 1994: 84). Much more specifically however, Tahiti has been seen by outsiders as both highly scented and highly sexualized right from the beginning. ${ }^{5}$ In the French (and more broadly Western) imaginary, Polynesia and the South Seas have long been associated with supposedly open and free sexuality, and Tahiti in particular has played a central role in this fantasy. Ever since Captain James Cook discovered the island in 1767, and especially since the French captain Baron de Bougainville arrived in 1768 and subsequently published an account of his voyage, the mention of Tahiti has evoked images of nubile maidens swimming eagerly to the boats of waiting sailors, removing their garments, and freely offering themselves up to the visitors, in exchange for perhaps a metal nail or knife. Of course the reality of these colonial encounters was far more complex than the simplistic accounts offered in the West in the eighteenth century. ${ }^{6}$ But nevertheless, among the many locations colonized during the eighteenth and nineteenth centuries, Tahiti and Polynesia stand out for the degree to which the sexual component of their identities was dominant. One could say that whereas for other colonized areas, the supposed task of the colonizer was to suppress violence, or ignorance, or pestilence, or nomadism, or resistance, for the colonizers of Tahiti, especially the missionaries who arrived in 1797 and the French Catholics who took over in 1845, the foremost task was understood to be the suppression of sexuality, to a degree unique in the 
colonized world. This is not to say that struggles over sexuality are not a common theme of colonial and postcolonial relations generally; rather, the unique supposed 'freedom' of sexual relations in early Tahiti, the attractiveness of this freedom to many in the West and its challenge to Western mores, and the fierce need to both re-imagine and repress it on the part of others in the West, has made the stakes surrounding sexuality especially high in Tahiti.

Historical records amply document this point, and recent literary production in French by Tahitian authors, such as Louise Peltzer's Lettre à Poutaveri, or Arioi by Vairaumati no Ra'iātea, has focused heavily on the missionization period and the imposition of nineteenth century Western bourgeois standards of sexual conduct on Tahiti and the Society Islands. ${ }^{7}$ In the eyes especially of the Protestant and Catholic Churches, the Tahitians have had the dubious task of both restraining their own sexuality and resisting Westerners' sexual impulses.

For this reason, though Sophie's mother Amélie disapproves of much of Sophie's odoriferous exploration of Pape'ete and the surrounding countryside, it is not at those moments that she intervenes most strongly to punish and prevent; rather, it is precisely at the moments of sexualized explorations of the female body that she steps in to reestablish order. This repression concludes the novel in fact: just as Sophie seems on the verge of constructing a true démie identity and falling in love with a young Tahitian man, she is sent back to France for schooling by her mother. This moment underscores the importance of Catholic education, the other key source of French authority and restriction in Sophie's life. While Amélie and the Catholic sisters do not always agree in their rules and methods, they largely cooperate in their efforts at control and surveillance of Sophie's body. 
These scenes invite a reading from a Foucaldian framework, with Sophie's experiencing of French authority, particularly in the school, and the Tahitian experience more generally understood as an attempt by a European authority to impose bodily discipline on its colonized subjects. Sophie, and Tahitians at large, are meant to progress from an underdeveloped state of civilization to a higher one, to rid themselves of base habits such as bathing in the nude (74-5), blowing one's nose with one's fingers (75), speaking 'le parler local' (83), provocative dance (121), or using indigenous or traditional medicine (140), through the controlling discipline of the school. As Ann Laura Stoler has argued, colonialism, race and sexuality are intricately entangled in the exercize of surveillance and power: as in the Dutch East Indies, where 'white endogamy, attentive parenting, Dutch-language training, and surveillance of servants' were key priorities (2002:151), the same process can be seen in Hutu Päinu, with endogamy the most central issue of all. Most generally, the behavior of the Dutch and the French in Tahiti can be read theoretically as an effort to construct 'cultures' -- and an implicit theoretical model of 'culture' -based on difference and disjunction. The pervasion of smell, along with bodily contacts between Sophie and those around her, continually undermine such models.

Stoler further shows how 'fears of [children's] affections for those bodies that should not touch them' (2002:155) were a key component of colonial 'cordon[ing] off' (156). Thus the battle between Sophie and her mother plays out in the realm of the senses and the body. During these instances of maternal discipline, Sophie is often dragged back to her 'French' side after a perceived transgression to the 'Tahitian' side. These two sides are marked by the senses and bodily comportment with which they are associated. In the following example, Sophie gives in to 
the temptation to dance with her Tahitian neighbors, only to be quickly recalled in anger by the rational maternal authority:

Sophie résiste une fois, deux fois à la tentation de danser, mais à la troisième, elle craque et invite Joël en riant $[\ldots]$

- Sophie ! Reviens à la maison.

Adieu joie. Finie la fête. La voisine fait une mimique désolée [...] La fillette la remercie et l'embrasse pour le plaisir de sentir l'odeur du mono’ $i$ de ses cheveux et la douceur enveloppante de ses bras. De retour chez elle, des reproches maternels l'accueillent : - Comment oses-tu te déhancher et te dévergonder ainsi, parmi ces gens ? Tu n’as donc aucune retenue ? (148)

The physical pleasure Sophie feels in dance and music is echoed in the touch and the smell of the neighbor, the smell of her hair and the 'douceur enveloppante' of her arms, all pleasures denied to her by her mother, who greets her not with touch but with harsh words, condemning her for giving expression to her sexualized body. The choice of the verb 'se dévergonder' here evokes a lack of shame and an unbound femininity, precisely what Sophie's mother tries to prevent.

For Sophie, touch especially is associated with pleasure, happiness and love, and a series of Tahitian women, including the neighbor with the mono ' $i$-scented hair, come into her life and serve as a model for a different, Tahitian, kind of mothering. Here, two examples, the first with an elderly Tahitian healer, and the second with Vanaa, the woman her mother hires to clean their house: 
Une fois, la vieille femme caresse l'épaule de l'enfant, qui sait instantanément qu'elle est admise dans son affection [...] Elle trouve magique cette façon qu'ont les gens du pays de signifier l'adoption de quelqu'un, par ce toucher affectueux, léger, dans le dos ou sur l'épaule, accompagné d'un sourire merveilleux. Elle lui renvoie spontanément le message en l'embrassant. (141)

- Dis, Vanaa, comment m'aimes-tu ?

- Je t'aime avec mes 'á'au [heart/gut]. Là, dit-elle, en indiquant son ventre.

Jamais elle n'a vécu cela auprès de sa mère, ni même auprès de sa grand-mère lorsqu'elle était toute petite. Elle en est intimement convaincue. (67)

This Tahitian touch is 'magique' to Sophie, and again, as in the scene with the neighbor, this touch stands alone, with no need for speech, while her mother seems to have nothing but words for her. In the second quote, Sophie explicitly contrasts Vanaa's love - which, throughout the book, is associated with free and easy expression of love through physical affection - with the love of her French mother and grandmother. Vanaa here seems to point to another hierarchy that can be turned, literally, on its head: she loves with her stomach and entrails, which, like the sense of smell, are bodily regions best not mentioned in polite bourgeois society. They are a seat of disease and disgusting physical processes that must be partitioned off from the higher, more civilized regions of the heart and head.

In light of this dynamic of control, we can now return to the earlier-cited chapter on the July Festival, and consider more closely the interplay of scent and sexuality. Soon after the dancing in the streets is finished and the family has concluded the meal and ice cream dessert, 
Sophie meets her girlfriend Stanley at a highly questionable bar known as Quinn's, where the 'parfums' of Tahitian flowers (tiare) and oils (mono'i) are pervasive, but also mixed with the 'écoeurante' odor of Pompéia perfume (116). The double meaning of 'parfum' in this passage simultaneously contrasts the indigenous smells of Tahiti with the artificially-introduced western ones, and also refuses the French/European schema of disgust as opposed to the pleasure of perfume by ironically qualifying the French perfume itself as the disgusting element. In so doing, it establishes a local understanding of the word 'parfum' which refuses the aesthetic and sociological judgments of bourgeois French society. ${ }^{8}$ At the same time, all three of the odors can be considered as gendered feminine (though men can also wear a tiare) in terms of the usage of the items or products in Tahiti. Both mono' $i$ oil and the tiare flower are pervasive within the modern Tahitian imagery of love and sexuality, as a look at the titles of popular Tahitian songs illustrates. ${ }^{9}$ The passage thus establishes competing tropes of female sexuality as well as 'parfum', and even more interestingly, for the first time moves away from the earlier poetics of scent in which juxtaposition and admixture were celebrated, along with a general openness to all scents, towards a more binary and judgmental perspective which rejects certain scents.

The two young girls then head off to find Stanley's American 'friend' (a 40-something yachtsman pursuing the 14-year-old [female] Stanley). On the way, they stop to urinate outdoors on the beach, under the stars, in another jarring (for western utopian myths) juxtaposition of paradise imagery and bodily necessity. They then arrive at the yacht, where a grotesque parody of the initial Tahitian encounter with Westerners as described by Bougainville is played out between the older Western man and the young Tahitian girl: 'deux grosses mains happent le corps malingre de Stanley et le cale contre un ventre proéminent' (117), and the American precedes to have his pleasure with Stanley, eagerly eyeing Sophie as well, who barely escapes 
with her full virginity intact. As open as she is to embodied experience, the one thing that leaves her full of 'dégoût' and feeling 'violentée' and 'souillée' (118) is the encounter with the American. Note that in contrast to her receptivity to sensual encounter and even invasion, the American seems completely closed to this form of knowledge. Instead his hands 'happent' the body of Stanley, then one hand 's'avance' towards Sophie's bosom, then 'il fourrage dans la culotte' (118) - all acts of active grasping and seizing which stand symbolically for Western attitudes towards Tahiti generally, and Tahitian women in particular, in the immediate postcontact period and ever since. This aggression forces Sophie into a position of defensiveness which disrupts the sensual, open epistemology of the body and the lower senses which otherwise dominates the month of the festival, and indeed, her entire existence. Just to reinforce this message, a very similar scene occurs on a French naval boat later in the book, when Sophie and her friends venture on board to meet the young sailors, and the atmosphere full of 'parfums de tiare et de moto' $i$ [sic: mono'i]' is negatively qualified as 'étourdissant' (292-293).

From this point on, the July festival never reaches its previous heights for Sophie, despite some more very agreeable opportunities to dance, and by the end 'les feuilles d'ornements et les fougères sont desséchées, rétrécies, brisées. Leur parfum s'est évaporé pour être remplacé par des relents de bière et de vieille urine' (125). The thematics and poetics of scent which dominated the first half of the chapter are replaced by images of what anthropologist Deborah Jackson (2011) has called 'dysplacement,' the opposite of the threat of the immigrant or lower class person to the one in power. Dysplacement occurs when foreign influences and scents have rendered the local setting objectionable and alien to the indigenous inhabitants, and even one's own body can feel invaded and alienated from the subject through this process (2011: 608). Here, 
the local 'parfum' is gone, and the smell of urine and even excrement on the beach, mixed with the odors of the reef and the shimmering of the stars, which earlier seemed to be simply other forms of embodied experience, have been replaced by merely stale 'relents,' stinking leftovers detached from the body. ${ }^{10}$

Teissier-Landgraf thus situates Sophie's struggle within the larger context of the Tahitian colonial and sexual experience. The first Europeans to arrive discovered and aggressively exploited un-covered Tahitian (female) bodies, then the missionaries and the colonial government tried to cover what had been un-covered. Sophie's experience recapitulates this process, though in reverse. The choice of a young female narrator is, in the context of this sexualized colonial history, clearly an especially important one. Since she is half French, her arrival in French Polynesia ironically mirrors those of the male European voyagers who came before her. But as we have seen, Sophie's Tahitian discoveries tend to be of a very different order than those of Bougainville and his ilk, focusing on openness to perfusion rather than a desire for acquisition. Her encounters and experiences overturn the traditional European male writing of the discovery of Tahiti.

The novel refuses a simplistic gendering of the events in terms of European male acquisitiveness and Tahitian female defensiveness, however. As already seen, Sophie endures great conflict with her French mother as well. Her mother and the Catholic school nuns broadly represent the forces of French female suppression of sensual experience. This involves both a degree of collaboration in the colonial endeavor described above, but also resistance to elements of its masculine sexual acquisitiveness. The novel is not shy about depicting the sexually aggressive instincts of Tahitian men, either, it should be noted. But if we understand Sophie's 
mother as broadly representing the repressive side of the French colonizing presence within Sophie's life, then her struggle to escape her mother's plans resonates with the struggle of Tahitian women to escape Euro-French definition and dominance. This is just the reading of Sophie that Tahitian novelist Ari'irau proposes in her own 2006 novel Matamimi, which is written as a letter to her own mixed-race daughter: she describes Sophie as 'La petite enfant à l'âme polynésienne chérie de tous sauf de sa mère la France' (13).

At the deepest level, this series of scenes, from the joyous, raucous, and odoriferous festival to the 'dégoût' of the encounters with the American and the sailors, suggests that the Euro-French encounter with Tahiti involved two different epistemologies of body and knowledge, which continued to be enacted at least into the post-World-War-II era of the novel, and indeed into the present. From the Euro-French (and American) perspective, 'disgust' in its fundamental form consists in the inability to compartmentalize inputs from the lower senses, and the inability to isolate oneself from these inputs (via social or discursive controls), while 'pleasure' is inseparably linked to active control and even seizure. From Sophie's local perspective however, 'pleasure' in its fundamental form lies specifically in those lower senses, in all forms, fragrant or otherwise, while 'disgust' could be seen as a kind of dysplacement and mourning for the necessary closure and distancing of the body from the pleasures of sensual invasion in the new context of Euro-Western grasping and acquisitiveness, as well as EuroWestern discourses and institutions of control. Indeed, Sophie's disgust is intimately linked to mourning: '[elle] pleure son amie [Stanley] perdue à tout jamais. Le dégoût la tenaille au souvenir du sourire de la fillette et de son petit téton dressé entre les gros doigts du bonhomme' (118). The scene suggests for the Tahitian two choices in the face of this new Western form of 
invasiveness: submission to invasion (whether sexual, psychological, or political), or a resistance and closing off of the body, which necessarily constitutes a compromise of the Tahitian epistemology of the body and an alienation from it. In the latter case, the power of perfume now understandable as a symbol of the lower senses generally and the pleasures and rhythms of ephemeral encounter - will necessarily 'evaporate', leaving a tragically degraded corporeal experience where the odor of stale beer and urine constitute the dominant residue. Yet as the scenes of the chapter 'Les Fêtes du Tiurai' suggest, the very ephemeral and powerful nature of 'perfume' in its metaphorical and poetic sense, so rich with irony and the potential for unconstrained encounters, allows a continued resistance to the discursive modes of colonial control exercized through writing and speech. 'Perfume' can be understood as the noncategorical, the pervading, both a social and a literary sense. In this Tahitian sense, 'perfume' is both the agreeable odor and the stench, and even more, both together, ironically echoing each other.

\section{Hutu Pāinu and the Local Tahitian Literary Context}

The opening scene of encounter with the island, with which we began, seemed to echo the classic motifs of the Western imaginary of Tahiti as a flowery and fragrant, sexualized paradise. Alternately, it also seemed to suggest a particularly Tahitian view of fragrance, linking Tahiti to flowers and perfume. But the text gradually both enriches and undermines these motifs. Most generally, one might think of that scene as a metaphorical question for the reader about how to approach Tahiti generally, the modern literature of Tahiti more specifically, and Hutu Pāinu in particular. The primary Tahitian literary journal, Littérama'ohi, of which the author of this novel is a founding member, is notable for its openness to French language, Polynesian 
languages and themes, as well as Chinese (there is a large Hakka community in French Polynesia), plus other international languages of the Pacific such as English and Spanish. This openness is in fact explicitly clarified in the opening statement which appears in every edition as well as on the website (http://www.lehman.cuny.edu/ile.en.ile/litteramaohi/presentation.html), as well as through the tri-lingual subtitles on the cover, in French, Chinese and Tahitian. Hutu Päinu is strongly traversed by all of these influences in its content, and in many ways could be seen as the literary realization of the vision of Littérama'ohi's founding statement of multilingual and multi-cultural exploration of the region of French Polynesia and its connections to the broader world. Highly evident in recent theoretical readings of Tahitian literature are the themes of voyaging, expressed through the Polynesia canoe, and the métissage related to this, with a focus on Pacific and Oceanic themes and connections (see in particular special issues of The International Journal of Francophone Studies in 2005 (vol. 8:3) and 2008 (vol. 11:4), especially articles by Kareva Mateata-Allain (2005, 2008) and Michelle Keown (2008)). But even more broadly, a number of other recent Tahitian works explore intimate connections with indigenous America (Moetai Brotherson, Le Roi Absent) or with the popular culture of the US, inflected through the Chinese world of French Polynesia (Jimmy Ly, Histoires de Feu, de Flamme et de Femmes, especially 'Le Tyson de coqs de combat et de mon cousin Pouen'), to take two examples. These and many other Tahitian works play with and resist outside imaginaries of the colony, the island, or La Nouvelle Cythère. But Hutu Päinu, as much or more so, takes some of the most central emblems of Tahiti (for both outsiders and insiders) and refigures them in ways which resist both Western/outsider and straightforward Tahitian/insider readings, or even Oceanic-style readings. The hermeneutics of scent in the text can certainly be 
read in terms of a general postcolonial and international olfactory poetics (with strong roots in French literary culture of the Second Empire and Third Republic), which offers pervasion, irony and indeterminacy as a foil to social and discursive boundaries, divisions, and controls. But as the many examples in this article have illustrated, at its most subtle and profound levels, the poetics of scent in the text refuses just this kind of simplistic opposition between a purely Tahitian or postcolonial openness and indeterminacy and a purely French or colonial sense of order and closure. Like Sophie, the text is actually open to smells and sensations from French and Catholic sources as much as any other, from bakery items to religious icons, and Sophie's friends represent many different origins. Patrick Sultan (2010: 138-39), inspired by remarks from S. Andre (2001), suggests dueling tendencies in contemporary Tahitian literature between a binarist outsider-versus-indigenous postcolonial perspective (best illustrated in the work of Chantal Spitz) and a nascent nationalist perspective which places lesser emphasis on ethno-racial distinctions, illustrated in the work of Stephanie Ari'irau Richard, Jean-Marc Tera'ituatini Pambrun, and Chantal Peu. Sultan argues that the latter persepctive must be understood as ‘plurielle, multi-identitaire,' and (citing Andre) ‘placée sour le signe de la continuité, de l'interdépendance [...et] de la relativisation des concepts de résistance à l'oppression coloniale' (139). Teissier-Landgraf's novel seems to incline in this same direction, and in the sequel, which recounts Sophie's life in France, Sophie says at a meeting of Tahitian students:

Regardons la réalité en face. Avec honnêteté. Il n'existeplus de purs Mā'ohi. Pourquoi, au nom de cette identité, nous opposer à celle du Popa 'ā que nous ne serons jamais vraiment? Tout est faussé. N'est-ce pas courir après un mythe ? Nos références culturelles sont issues d'une 
part des perceptions déformées des anciens missionaires, et d'autre part de la mémoire sélective des anciens [Tahitiens]. (Ätea roa, 227)

Crucially, it is the act of sexual acquisitiveness and aggression which fundamentally closes down the open potentials of Tahiti, and produces responses which are binary in their nature. Foreign desires foreclose on local possibilities. It is not France or French language and culture (or America or English) per se that are presented as necessarily negative forces within the local domain of Tahiti, at least in this text, but rather acquisitive desires for the 'local' - desires which read that local in terms of a narrowly historical perspective on sexualized and fragrant indigeneity, rather than recognizing the multiplicities and contradictions of that local existence. In a similar vein, we could say that attempts to read Hutu Päinu purely from the standpoint of the postcolonial dynamic of 'Tahitian' 'cultural' pervasion versus 'French' control are a similar form of 'international aggression' which risks producing the same binaries, foreclosing on the narrative in the way that Sophie's mother does on her daughter's body. The encounter scene in the text broadly evokes outsiders' first encounters with a supposedly 'unspoiled' and 'sensual' Tahiti, only to progressively complicate them as the text proceeds. A fundamental goal of many of founders of Littérama'ohi, and Teissier-Landgraf in particular, is to avoid this tendency in both the production and reception of the literature of French Polynesia. In an essay in Litterama'ohi she writes:

Spontanément, nous réagissons et nous pensons pour la plupart d'entre nous soit en Ma’ohi, soit en Français, soit en Chinois, soit en Américain....Nous agissons tantôt 
selon une hiérarchie de valeurs, tantôt selon une autre, tantôt...? Qui pourrait bien le savoir ? Même nous-mêmes...Un vrai "Shop-Suei”... qui réunit toutes races et toutes générations confondues à la convivialité d'une même table où s'échangent toutes les langues et tous les styles. (2003: 49)

Her work could be seen as an effort to (re)open Tahitian society and literature to its disparate potentials: not to have it stand as an avatar of the purely indigenous in its local context, but perhaps even more importantly, not to have this literature and its readings be closed down by the kinds of sexualized, desiring encounters which the Tahitian imaginary risks evoking from outside - including postcolonial variants of those desires. The 'local', from this perspective, is constituted by a unique conjunction of translocal influences, and the task of the reader is to respect and understand that specificity. As Ari'irau writes (and fears) in Matamimi, 'la littérature polynésienne vivra le destin de ses îles. Elle sera désirée, telle une terra incognita, par des âmes rêveuses et étrangères' (87). Let us not be those strangers.

\section{References}

Ameeriar, Lalaie (2012), 'The Sanitized Sensorium', American Anthropologist, 114: 3, pp. 50920 .

André, S. (2001), 'La Littérature polynésienne en français.' In J. Bessière and J-M. Moura, (eds.), Littératures postcoloniales et francophonie, Paris: Champion.

Ari'irau (2006), Matamimi, ou La vie nous attend, Pirae, French Polynesia: Au Vent des Îles.

Barrows, Susanna (1981), Distorting Mirrors: Visions of the Crowd in Late 19th Century France, New Haven: Yale. 
Batty, Clare (2010), 'Olfactory Experience I: The Context of Olfactory Experience', Philosophy Compass, 5: 12, pp. 1137-46.

Bougainville, Louis-Antoine, Comte de (1771), Le Voyage Autour du Monde, par la frégate La Boudeuse et la flûte l'Etoile, Paris.

Brotherson, Moetai (2007), Le roi absent, Piraie, French Polynesia: Au Vent des Îles.

Classen, Constance, David Howes, and Anthony Synnott (1994), Aroma: The Cultural History of Smell, London: Routledge.

Clifford, James (1988), The Predicament of Culture: Twentieth-Cenutry Ethnography, Literature, and Art, Cambridge: Harvard University Press.

Corbin, Alain (1986), The Foul and the Fragrant: Odor and the French Social Imagination, Cambridge: Harvard University Press.

Curtis, Bruce (2008), "I can tell by the way you smell": Dietetics, Smell, Social Theory', Senses and Society, 3: 1, pp. 5-22.

Drobnick, Jim (2012), 'Towards an Olfactory Art History: The Mingled, Fatal, and Rejuvenating Perfumes of Paul Gauguin', Senses and Society, 7: 2, pp. 196-208.

Feigenbaum, Suzanne (2004), 'Color and Olfactive Perception in the Eyes of Peirce and Collette', Semiotica, 150, pp. 419-38.

Foucault, Michel (1975), Surveiller et Punir, Paris: Gallimard.

Gauguin, Paul (1947), Noa Noa: Voyage à Tahiti, Stockholm: V. Petterson.

Gupta, Akhil and James Ferguson (1992), 'Beyond "Culture”: Space, Identity and the Politics of Difference’, Cultural Anthropology 7: 1, pp. 6-23.

Hargreaves, Alec G., Charles Forsdick and David Murphy, eds. (2010), Transnational French Studies: Postcolonialism and Litterature-monde, Liverpool: Liverpool University Press.

Hugh Davis (2004), “"How Do You Sniff?” Havelock Ellis and Olfactory Representation in "Nausica", James Joyce Quarterly, 41, pp. 421-40.

Jackson, Deborah Davis (2011), 'Scents of Place: the Dysplacement of a First Nations Community in Canada', American Anthropologist, 113: 4, pp. 606-18.

Jütte, Robert (2005), A History of the Senses: From Antiquity to Cyberspace, Malden: Polity 
Press.

Keown, Michelle (2008), "'Our sea of islands": Migration and métissage in contemporary Polynesian writing'. International Journal of Francophone Studies, 11:4, pp. 503-522.

Kern, Stephen (1974), 'Olfactory Ontology and Scented Harmonies: "On the History of Smell”, Journal of Popular Culture, 7: 4, pp. 816-24.

Lai, Paul (2008), 'Stinky Bodies: Mythological Futures and the Olfactory Sense in Larissa Lai's Salt Fish Girl', MELUS, 33: 4, pp. 167-87.

Loti, Pierre ([1880] 1924), Le Mariage de Loti, Paris : Calmann-Levy.

Ly, Jimmy M. (2006), Histoires de feu, de flame et de femmes, Tahiti: self-published.

Mateata-Allain, Kareva (2005), 'Oceanic peoples in dialogue: French Polynesian literature as transnational link,' International Journal of Francophone Studies, 8:3, pp. 269-88.

Mateata-Allain, Kareva (2008), 'Métissage and migration through the metaphor of the va'a or canoe: intellectual cross-fertilization of $M a$ 'ohi literature within an Oceanic context', International Journal of Francophone Studies, 11:4, pp. 601-621.

Melville, Herman ([1846] 1935), Typee: A Romance of the South Seas, New York: Heritage Press.

W.H. Perason (1969), 'European Intimidation and the Myth of Tahiti,' The Journal of Pacific History, 4, pp. 199-217.

Peltzer, Louise (2002), Lettre à Poutaveri [Bougainville], Pirae, French Polynesia: Au Vent des Îles.

Ra'iātea, Vairaumati no (2001), Arioi, Pirae, French Polynesia: Au Vent des Îles.

Ramsey-Kurz, Helga and Geetha Ganapathy-Dové (eds.) (2011), Projections of Paradise: Ideal Elsewheres in Post-colonial Literatures, Amsterdam: Rodopi.

Rancière, Jacques (2004), The Politics of Aesthetics: The Distribution of the Sensible [trans. Gabriel Rockhill], London: Continuum.

Ratheiser, Ulla (2011), 'The Scent of Paradise: Michael Ondaatje's "The Cinnamon Peeler", in Helga Ramsey-Kurz and Geetha Ganapathy-Dové (eds.), Projections of Paradise: Ideal Elsewheres in Post-colonial Literatures, Amsterdam: Rodopi, pp. 161-181.

Richard, Stéphanie Ari'irau (2007), 'Le corps humain, c'est le corps social', Littérama'ohi, 13, pp. 154-59. 
Roubin, Lucienne A. (2006), 'Fragrant Signals and Festive Spaces in Eurasia', in Jim Drobnick, (ed.), The Smell Culture Reader, New York: Berg.

Scruton, Roger (1979), The aesthetics of architecture, Vol. 8, London: Methuen.

Segalen, Victor ([1907] 1995, Les Immémoriaux, in Oeuvres Complètes, Paris: R. Laffont, Vol. 1, pp. 107-247.

Shiner, Larry and Yulia Kriskovets (2007), 'The Aesthetics of Smelly Art', Journal of Aesthetics and Art Criticism, 65: 3, pp. 273-86.

Stoler, Ann Laura (2002), Carnal Knowledge and Imperial Power: Race and the Intimate in Colonial Rule, Berkeley: University of California Press.

Sultan, Patrick (2010), 'Peut-on parler de "Littérature polynésienne francophone”?'. Littérama'ohi, 18, pp. 136-46.

Teissier-Landgraf, Marie-Claude (2003), 'Une langue pour imaginer', Littérama'ohi, 4, pp. 4449.

Teissier-Landgraf, Marie-Claude (2004), Hutu Päinu: Tahiti, racines et déchirements, Pirae, French Polynesia: Au Vent des Îles.

Teissier-Landgraf, Marie-Claude (2006), Attea roa : Voyages inattendus, Piraie, French Polynesia : Au Vent des Îles.

Terranova, Charissa N. (2007), 'Smell of the City: Miasma as a Code of Crisis in Post-war French Cinema', Senses and Society, 2:2, pp. 137-53.

1 Bougainville, Le Voyage Autour du Monde. See chapters 7-10. Gauguin's most famous writing on Tahiti is entitled Noanoa, which means 'fragrant' in Tahitian, more properly spelled no'ano'a. See Drobnick 2012 for an analysis of scent in the work and writings of Gauguin more generally as it relates to Tahiti. 
2 The choice of the word 'effluves' is an interesting one. The Littré dictionary gives a definition that brings us back to the ideas of The Foul and the Fragrant, with smell associated with both disease and desire: 'Terme de médecine. Nom de substances organiques altérées, tenues en suspension dans l'air, principalement aux endroits marécageux, et donnant particulièrement lieu à des fièvres intermittentes, rémittentes et continues [...] Fig. et dans le style néologique. Les effluves de la passion. Effluves énervants, délicieux.' Thus the term 'effluves' seems to bring to the fore the doubly dangerous nature of odors: dangerous to health and dangerously provocative of lustful desires.

3 There are numerous other scenes in the text that function around what might be called an 'aesthetics of the disgusting', notably on pp. 47, 49, 61, 114, 157, 280, 327, 345.

4 We should note that a related feature that is often emphasized in the text is cacophonous sound, as in the first scenes at the house in Pape'ete. Other examples are on pp. 105, 109, 115, 237, 339 .

5 In fact, though Bougainville emphasizes the verdant and fertile nature of Tahiti, he does not focus in particular on scent. Melville in Typee, gives much more prominence to flowers: 'the house was nearly filled with young females, fancifully decorated with flowers' (113); 'Flora was their jeweler' (135). By the late nineteenth century, representations of Tahiti heavily emphasize fragrance, in line with the general transformation of the status of the sense of smell. As already noted, Gauguin entitled his Tahitian notebook 'Fragrant' (Noa Noa) -- see also Drobnick 2012. In Les Immémoriaux, Victor Segalen opens his description of the Tahitian scene as follows : 'La brise nocturne, chargée des parfums terrestres, coulait 
odorante et froide' (111). In Le Mariage de Loti, Pierre Loti tells us that 'l'air était chargé de senteurs énervantes et inconnues' (17) when he first encounters his lover Rarahu.

6 See especially Pearson 1969. Pearson shows that the effusively welcoming treatment of Bougainville was in large part due to the violence wreaked on the Tahitians by Wallis during his visit immediately preceding Bougainville's arrival. Peltzer (2002); Vairaumati no Ra'iātea (2001). Note that both of these novels, like Hutu Pāinu, also feature young female narrators, so that they offer a view diametrically opposite that of the desiring (male) westerner.

8 It should be noted however that a resistance to perfume, in particular due to its artificiality, is prominent in the work of the French novelist Colette (see Feigenbaum 2004).

9 For example, see the song 'Hei no te tiare' ('A lei of tiare flowers/for the tiare [i.e. the beloved]') which includes the line 'hei no'ano'a' ('fragrant lei'), and also the song 'Mono'i, te hinu no'ano'a Tahiti' ('Mono'i, the fragrant Tahitian oil'). Similarly, there is another song 'Te pua no'ano'a' ('The fragrant flower') by the artist Heremoana Ma'ama'atuaiahutapu, and the list of songs mentioning either the tiare flower or the idea of fragrance could be extended greatly. Note however that not all of these songs concern love and sexuality narrowly speaking; the imagery can be used for a general sense of cherished value, and the Territorial Anthem also refers to the islands as a 'necklace of fragrant (no'ano'a) islands.' All of these songs can be found on Youtube (accessed December 19, 2012).

10 The theme of the invaded and politicized Tahitian body has been a focus of a number of recent local literary works, reaching its culminating image in the nuclear contamination of local bodies from French atomic testing, as Stephanie Richard illustrates (2007). 